\title{
Homebound Instruction
}

National Cancer Institute

\section{Source}

National Cancer Institute. Homebound Instruction. NCI Thesaurus. Code C159514.

Instruction to children unable to attend school because of physical disabilities, special health problems, or temporary injuries or illness. This instruction is usually provided by the local school district, usually with a teacher visiting the child in their home, but would include alternative methods, such as online teaching. 